\title{
Influence of the Pacific Decadal Oscillation on Hydrochemistry of the Rio Grande, USA, and Mexico
}

\author{
Fasong Yuan \\ Cleveland State University, f.yuan06@csuohio.edu \\ Seiichi Miyamoto \\ Texas A\&M University
}

Follow this and additional works at: https://engagedscholarship.csuohio.edu/scibges_facpub

Part of the Biology Commons

How does access to this work benefit you? Let us know!

\section{Recommended Citation}

Yuan, F., and S. Miyamoto (2004), Influence of the Pacific Decadal Oscillation on hydrochemistry of the Rio Grande, USA, and Mexico, Geochem. Geophys. Geosyst., 5(12), Q12010, doi:10.1029/2004GC000769.

This Article is brought to you for free and open access by the Biological, Geological, and Environmental Sciences Department at EngagedScholarship@CSU. It has been accepted for inclusion in Biological, Geological, and Environmental Faculty Publications by an authorized administrator of EngagedScholarship@CSU. For more information, please contact library.es@csuohio.edu. 


\title{
Influence of the Pacific Decadal Oscillation on hydrochemistry of the Rio Grande, USA, and Mexico
}

\author{
Fasong Yuan and Seiichi Miyamoto \\ Agricultural Research and Extension Center, Texas A\&M University, 1380 A\&M Circle, El Paso, Texas 79927, USA \\ (fyuan@tamu.edu)
}

[1] The hydrochemistry has been examined using the major element composition of river water at 12 gauging stations along the Rio Grande. As the Rio Grande Basin consists of two watersheds that have different hydrologic and climatic regimes, two chloride concentration records from the El Paso and Falcon Dam gauging stations have been extracted to reflect long-term variability in river chemistry of the upper and lower basins over the last 50-70 years. Both records contain decadal variability in chloride concentration but are different in nature. The chloride concentration record from the upper basin displays a distinct pattern of decadal variability similar to the Pacific Decadal Oscillation (PDO). This indicates the chloride concentration at El Paso is largely determined by the amount of stream discharge of the upper basin that is associated with the PDO. Conversely, there is no such pattern of decadal variability in the chloride concentration record from the lower basin though several of the chloride concentration maxima coincide with minima in the PDO index. Instead, the chloride concentration record from the lower basin contains a progressively increasing trend of chloride concentration from 1970 to 1990, suggesting that anthropogenic disturbances (e.g., dam constructions and increased irrigation demands) may also play a role in intervening long-term changes in river chemistry.

Components: 5139 words, 5 figures, 2 tables.

Keywords: Rio Grande; Pacific Decadal Oscillation; PDO; stream discharge; chloride concentration; hydrochemistry.

Index Terms: 1045 Geochemistry: Low-temperature geochemistry; 1860 Hydrology: Runoff and streamflow; 1857 Hydrology: Reservoirs (surface).

Received 8 June 2004; Revised 6 October 2004; Accepted 22 October 2004; Published 21 December 2004.

Yuan, F., and S. Miyamoto (2004), Influence of the Pacific Decadal Oscillation on hydrochemistry of the Rio Grande, USA, and Mexico, Geochem. Geophys. Geosyst., 5, Q12010, doi:10.1029/2004GC000769.

\section{Introduction}

[2] Long-term variability in river chemistry needs to be assessed for effective management of water and land resources, particularly in semiarid regions with rapid population and economics growth. Pioneered by Clark [1924] and followed by Livingstone [1963], water chemistry has been extensively studied over the major world rivers, notably the Amazon [Gibbs, 1972; Stallard and Edmond, 1981, 1983, 1987; Markewitz et al., 2001], the Mississippi [Clark et al., 2003], the Mackenzie [Hitchon et al.,
1969; Levinson et al., 1969; Reeder et al., 1972], the Yangtze [Hu et al., 1982; Chen et al., 2002], and the Nile [Kempe, 1983; Dekov et al., 1997]. Unfortunately, most studies cover a relatively short period (typically a couple of years) and are only able to account for seasonal climatic and biotic fluctuations. Little is known about long-term changes in river chemistry at watershed scales.

[3] The river water of the Rio Grande is extensively diverted and allocated for agriculture, wetlands, and industrial and domestic users along the 
Rio Grande. Although highly variable across the basin, the concentration of total dissolved solids (TDS) is relatively high $\left(700-2000 \mathrm{mg} \mathrm{L}^{-1}\right)$ compared to other major rivers in North America. The causes of the relatively high TDS level have been the subject of investigation for nearly a century and remained not fully explained [Phillips et al., 2003]. The early work of the National Resource Committee [1938] concludes that it is ascribed to displacement of natural saline groundwater by agricultural drains. Wilcox [1957] suggests that evaporation in irrigated soils is responsible for the elevated salinity on the basis of his analysis of salt burdens along the upper Rio Grande. Gibbs [1970] also suggests that evaporation-crystallization is the main process for the high TDS in the Rio Grande. Phillips et al. [2003], using stable isotopic tracers, suggest that most of salinity increases along the upper Rio Grande are attributed to input from saline subsurface waters. These studies provide important insights into river chemistry of the Rio Grande, but ignore the fundamental impact of climatic fluctuations.

[4] It is now recognized that the El Niño/Southern Oscillation (ENSO) is the most potent source of global climate variability on interannual timescales, typically 2-7 years [Rasmussen and Wallace, 1983]. Recent studies have revealed a significant long-live ENSO-like pattern of the Pacific Decadal Oscillation (PDO) [Mantua et al., 1997; Zhang et al., 1997]. The PDO is essentially a recurring pattern of ocean-atmosphere covariability in which a warming of the eastern margin coincides a cooling of the central gyre, a lowering of sea level pressure (SLP) over the North Pacific and a heightening of SLP over the western U.S. Alternating PDO sign changes, termed as climatic regime shifts that occurred in 1924/25, 1946/47, and 1976/77, have had profound impacts on the physical and biological environments over the North Pacific and North America over the last century [Mantua et al., 1997; Mantua and Hare, 2002]. For example, Neal et al. [2002] report that changes in seasonal streamflow from six watersheds in Southeast Alaska are linked to the PDO modes. Streamflow in the Columbia River of the Pacific Northwest coast negatively correlates with the PDO index [Hamlet and Lettenmaier, 1999]. The Rio Grande receives snowmelt from winter storms in the southern Rocky Mountains and runoff from summer Mexican monsoons in the lower valleys. Wintertime precipitation in the American Southwest is associated with both ENSO and PDO modes of climatic oscillations [Gershunov and Barnett, 1998; Gutzler et al., 2002], but the relationship between summer monsoon rainfall and ENSO and/or PDO phenomena remains elusive [Adams and Comrie, 1997].

[5] In this paper, we examine streamflow and major element chemistry at 12 gauging stations along the Rio Grande. An analysis of the relationships among streamflow, reservoir volume/elevation, and chloride concentration records from the El Paso and Falcon Dam gauging stations spanning the last 50-70 years is performed. We compare these records with the PDO index to evaluate the impacts of climatic fluctuations on the changes in river chemistry of the Rio Grande.

\section{Basin Characteristics}

[6] The Rio Grande originates in the southern Rocky Mountains in Colorado, flows south through New Mexico, then turns southeast along the boundary between the United States and Mexico, and ultimately joins the Gulf of Mexico (Figure 1). It traverses several climatological zones from alpine tundra to Chihuahuan desert to coastal Gulf monsoon. Annual precipitation varies from $125 \mathrm{~cm}$ in the headwaters in southern Colorado to $20 \mathrm{~cm}$ in El Paso to $50 \mathrm{~cm}$ in Falcon. Three major reservoirs (Elephant Butte, Amistad, and Falcon) along the main channel were completed in 1916, 1968, and 1953, respectively. Besides, there are a number of smaller dams and irrigation works built across the basin. The Rio Conchos alone for example has been dammed at 10 different locations [Gutierrez and Borrego, 1999]. As a result, there has been a substantial reduction $(75 \%)$ in annual discharge of the Rio Grande to the Gulf of Mexico since construction of Falcon Dam [International Boundary and Water Commission, 2001].

[7] The Rio Grande Basin consists of two major watersheds; one originates from the southern slopes of the Rocky Mountains, the other from the eastern flank of the Sierra Madre Occidental in Mexico and the Pecos Basin of southeastern New Mexico and western Texas [Earl and Harrington, 1994; Miyamoto, 1996]. The 1906 treaty between the United States and Mexico set the boundary between the upper and lower basins at Fort Quitman, Texas. The upper Rio Grande is fed mainly by snowmelt from winter storms in its headwaters regions. Its streamflow decreases progressively from its headwaters in Colorado to El Paso, Texas and almost diminishes near Fort Quitman, about $125 \mathrm{~km}$ south of El Paso 


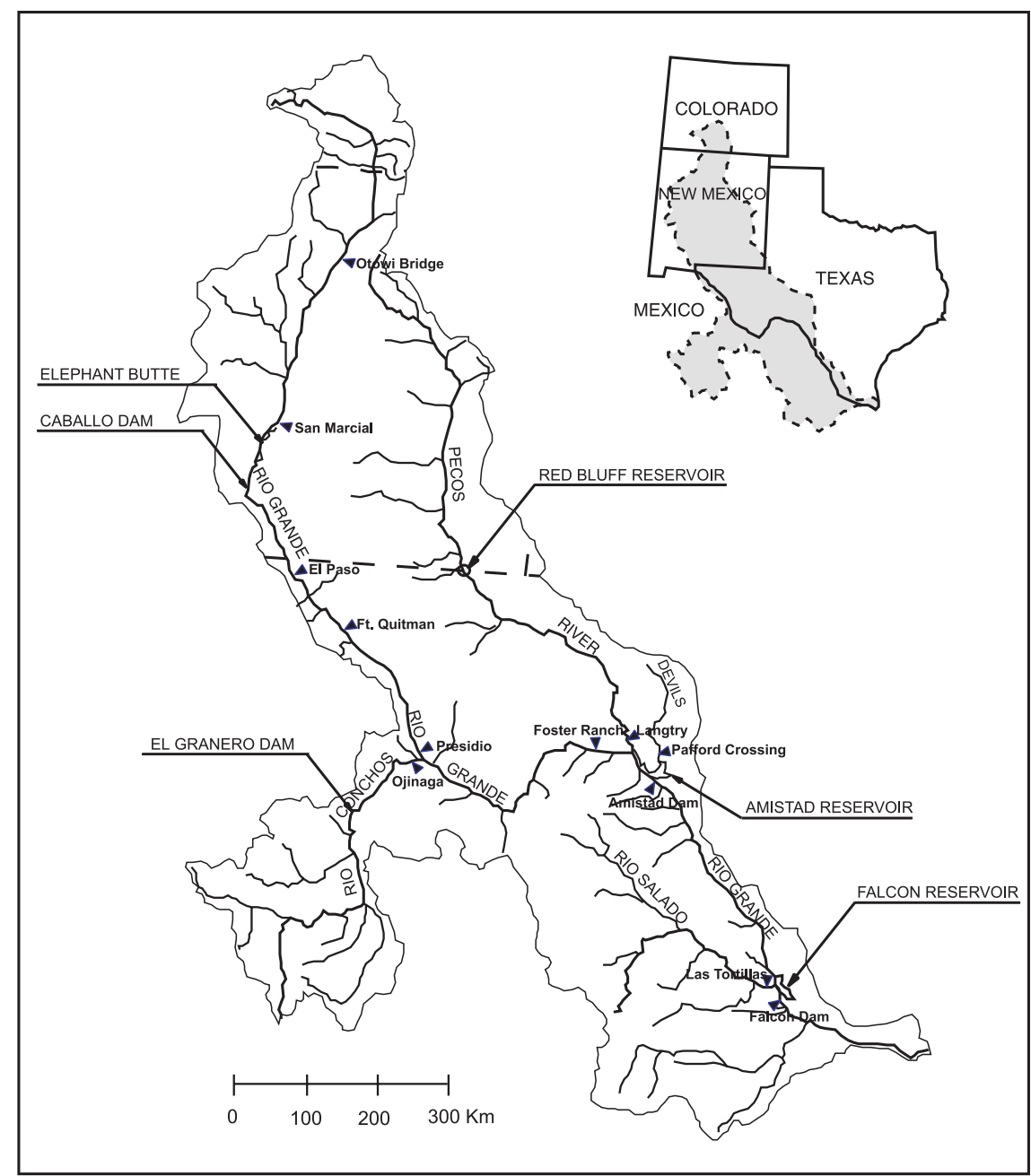

Figure 1. Location map of the Rio Grande and its tributaries. Solid triangles denote positions of major gauging stations whose flow and hydrochemical data are used and discussed. Original map data are from the U.S. Geological Survey.

(Figure 2). Average discharge at the El Paso station is $17 \mathrm{~m}^{3} / \mathrm{s}$ (Table 1). In contrast, the lower Rio Grande receives water mainly from four major tributaries of the Rio Conchos, the Rio Salado, the Devils River, and the Pecos River. There are a variety of moisture sources for the lower Rio Grande (e.g., monsoon rainfall, snowmelt, springflow, and agricultural drains, etc.), but most of the streamflow consists of runoff from convective activities (thunderstorms) of the summer Mexican monsoon. The upper Rio Grande contributes a small fraction $(\sim 6 \%)$ of water to the lower Rio Grande. Average discharge below Falcon is close to $100 \mathrm{~m}^{3} / \mathrm{s}$. In summary, the upper and lower basins have different climatic and hydrologic regimes.

[8] The river water of the Rio Grande is weakly alkaline $(\mathrm{pH}=7.8-8.2)$ (Table 1). The TDS concentration of river water increases from $271 \mathrm{mg} / \mathrm{l}$ at Otowi Bridge to near $2000 \mathrm{mg} / \mathrm{l}$ at Fort Quitman and back to about $700 \mathrm{mg} / \mathrm{l}$ in the Amistad and Falcon areas (Figure 2). Annual salt burden does not vary significantly in the upper basin, whereas it increases substantially along the main channel of the lower basin because the river receives additional salts from the tributaries. A large portion $(73 \%)$ of salt burden at Foster Ranch is from the Rio Conchos. The major element composition of the Rio Grande is dominated by the anions of $\mathrm{HCO}_{3}, \mathrm{SO}_{4}$, and $\mathrm{Cl}$, and the cations of $\mathrm{Na}$ and $\mathrm{Ca}$. Chloride concentration has a significant correlation with the concentrations of other major ions at many gauging stations along the Rio Grande (Table 2). It is noteworthy that the correlation between chloride and bicarbonate concentrations is positive in the upper basin but negative in the lower basin. This indicates that 


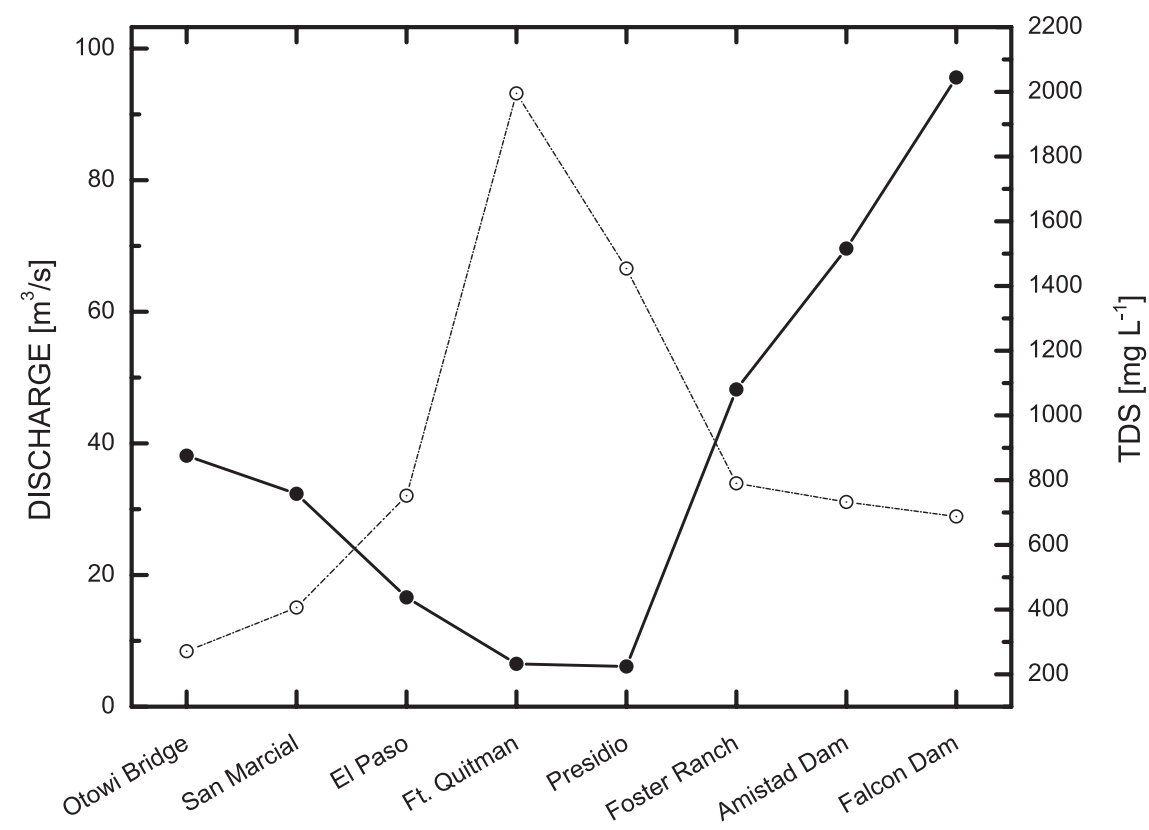

Figure 2. Changes in stream discharge (solid circles) and total dissolved solids (TDS, open circles) along the Rio Grande. Stream discharge rate is a simple arithmetic average of daily flow rates at each gauging station during the period 1969-1997, while TDS is a volume-weighted average using the results of chemical measurements and stream discharge rates during the same period. Original data are taken from USGS for the Otowi Bridge and San Marcial stations and from IBWC for the rest of stations.

the upper and lower basins have different river chemistry.

\section{Data and Methods}

[9] The El Paso and Falcon stations were chosen to investigate long-term changes in river chemistry of the upper and lower Rio Grande. This is because (1) the streamflow and chloride data at the two stations are nearly complete, (2) the salt burdens of the two stations are representative of the upper and lower basins (Table 1), and (3) the two sites have never been affected by seawater invasions during the instrumental era. Daily flow data were downloaded from the International Boundary and Water

Table 1. Mean Flow and Major Element Hydrochemistry of the Rio Grande ${ }^{a}$

\begin{tabular}{|c|c|c|c|c|c|c|c|c|c|c|c|c|}
\hline Station & $\begin{array}{l}\text { Flow, } \\
\mathrm{m}^{3} / \mathrm{s}\end{array}$ & $\begin{array}{l}\mathrm{pH}, \\
\text { S.U. }\end{array}$ & $\begin{array}{l}\mathrm{Ca}, \\
\mathrm{mg} / \mathrm{L}\end{array}$ & $\begin{array}{l}\mathrm{Mg}, \\
\mathrm{mg} / \mathrm{L}\end{array}$ & $\begin{array}{l}\mathrm{Na}, \\
\mathrm{mg} / \mathrm{L}\end{array}$ & $\begin{array}{c}\mathrm{K}, \\
\mathrm{mg} / \mathrm{L}\end{array}$ & $\begin{array}{c}\mathrm{HCO}_{3}, \\
\mathrm{mg} / \mathrm{L}\end{array}$ & $\begin{array}{l}\mathrm{SO}_{4}, \\
\mathrm{mg} / \mathrm{L}\end{array}$ & $\begin{array}{c}\mathrm{Cl}, \\
\mathrm{mg} / \mathrm{L}\end{array}$ & $\begin{array}{l}\mathrm{SiO}_{2}, \\
\mathrm{mg} / \mathrm{L}\end{array}$ & $\begin{array}{l}\mathrm{TDS}, \\
\mathrm{mg} / \mathrm{L}\end{array}$ & $\begin{array}{c}\text { Salt Burden, } \\
10^{3} \text { ton } / \mathrm{yr}\end{array}$ \\
\hline \multicolumn{13}{|c|}{ Main Channel } \\
\hline Otowi Bridge & 38 & 8.0 & 39 & 7 & 18 & 2.7 & 120 & 62 & 5 & 19 & 271 & 326 \\
\hline San Marcial & 32 & 7.9 & 50 & 9 & 43 & 4.3 & 153 & 105 & 22 & 20 & 406 & 414 \\
\hline El Paso & 17 & 7.9 & 75 & 16 & 129 & 6.9 & 184 & 222 & 102 & 15 & 752 & 394 \\
\hline Ft. Quitman & 7 & 8.0 & 162 & 40 & 441 & 9.5 & 222 & 515 & 587 & 19 & 1995 & 409 \\
\hline Presidio & 6 & 7.8 & 138 & 27 & 318 & 9.9 & 165 & 402 & 380 & 13 & 1454 & 280 \\
\hline Foster Ranch & 48 & 7.8 & 89 & 14 & 118 & 6.0 & 167 & 276 & 79 & 20 & 790 & 1201 \\
\hline Amistad Dam & 70 & 7.9 & 76 & 19 & 125 & 5.4 & 132 & 230 & 129 & 16 & 732 & 1608 \\
\hline Falcon Dam & 96 & 7.8 & 71 & 19 & 112 & 5.3 & 125 & 227 & 116 & 12 & 688 & 2073 \\
\hline \multicolumn{13}{|c|}{ Major Tributaries ${ }^{\mathrm{b}}$} \\
\hline Rio Conchos & 29 & 7.9 & 101 & 16 & 159 & 6.4 & 178 & 348 & 114 & 28 & 950 & 872 \\
\hline Pecos River & 8 & 7.8 & 123 & 51 & 334 & 7.0 & 165 & 335 & 544 & 13 & 1572 & 402 \\
\hline Devils River & 11 & 8.2 & 51 & 13 & 9 & 1.3 & 182 & 8 & 14 & 15 & 293 & 103 \\
\hline Rio Salado & 12 & 7.9 & 114 & 32 & 122 & 3.8 & 169 & 347 & 131 & 27 & 945 & 349 \\
\hline
\end{tabular}

${ }^{a}$ Flow-weighted mean of the chemical data at each station during the period 1969-1997 (original data from USGS for the Otowi Bridge and San Marcial stations and from IBWC for the rest of stations).

${ }^{b}$ Gauging stations of these tributaries are close to their confluences with the Rio Grande (see Figure 1). 
Table 2. Correlation Coefficients Between Concentrations of Chloride and Other Major Ions at Selected Stations Along the Rio Grande ${ }^{\mathrm{a}}$

\begin{tabular}{lccccccc}
\hline \multicolumn{1}{c}{ Sites } & $\mathrm{Ca}$ & $\mathrm{Mg}$ & $\mathrm{Na}$ & $\mathrm{K}$ & $\mathrm{HCO}_{3}$ & $\mathrm{SO}_{4}$ & $\mathrm{SiO}_{2}$ \\
\hline El Paso & $0.86^{*}$ & $0.93 *$ & $0.98^{*}$ & $0.78^{*}$ & $0.77 *$ & $0.95^{*}$ & $0.80 *$ \\
Foster Ranch & 0.32 & $0.82 *$ & $0.92^{*}$ & 0.52 & -0.07 & $0.65 *$ & -0.03 \\
Amistad & 0.27 & $0.92 *$ & $0.95^{*}$ & 0.45 & -0.24 & $0.82 *$ & -0.37 \\
Falcon & 0.18 & $0.79 *$ & $0.92 *$ & 0.53 & $-0.61 *$ & $0.72 *$ & 0.06 \\
\hline
\end{tabular}

${ }^{\mathrm{a}}$ Asterisk indicates significance level: $p<0.01$.

Commission (IBWC), United States and Mexico (http://www.ibwc.state.gov/html/rio_grande.html). Daily storage data of the Falcon Reservoir were also downloaded from the IBWC Web site and daily lake elevation data of the Elephant Butte were collected from the U.S. Bureau of Reclamation. Chloride concentration data were extracted from the IBWC Water Bulletin. Water samples have been collected by the IBWC with sampling frequency of one to five times per month, and analyzed by the U.S. Geological Survey (USGS). A small fraction $(<1 \%)$ of missing chloride data for the El Paso station were inferred from the results of specific conductance measurements.

[10] The PDO index is defined as the leading principal component of North Pacific monthly sea surface temperature variability [Mantua et al., 1997]. The PDO index data are available at the Climate Impacts Group, the University of Washington (http://jisao.washington.edu/pdo/ PDO.latest). Monthly mean flow and storage values were calculated through a simple arithmetic average using the daily data. Monthly mean chloride concentration values were computed through a flow-weighted average. Chloride flux is a product of flow and chloride concentration. The correlation analysis was performed using Microsoft Excel 2000. (Use of trademarks in this paper does not imply endorsement by the Texas A\&M University.)

\section{Results}

[11] The lake level of the Elephant Butte has fluctuated exceeding $40 \mathrm{~m}$ over the last 70 years, with a mean value of $1325 \mathrm{~m}$ (Figures $3 \mathrm{a}$ and $3 \mathrm{~b}$ ). This lake-level record has a similar pattern of variability as the PDO index. The lake level is generally above the average when the PDO index is positive and vice versa. Note that there is an $\sim 1$-year lag between the chloride and PDO records likely due to the impact of reservoir storage. The stream discharge at the El Paso station oscillates seasonally with a long-term average of $20 \mathrm{~m}^{3} / \mathrm{s}$ (Figure 3c).
The El Paso station had greater than normal river flow in the wet years of 1941 and 1986 and lower than normal river flow in the dry years of 1950 , 1955, 1964, 1971, and 1978. Again, most of the droughts occurred in the period when the PDO index was negative. The chloride concentration at El Paso was inversely related to stream discharge (Figures $3 \mathrm{c}$ and $3 \mathrm{~d}$ ). The arithmetic mean of the chloride concentration is $167 \mathrm{mg} \mathrm{L}^{-1}$, which is larger than the flow-weighted mean of $102 \mathrm{mg} \mathrm{L}^{-1}$ (Table 1) due to a more frequent occurrence of low-flow month with higher chloride concentration. The chloride concentration was generally above the average during the negative PDO phase, and below the average during the positive PDO phase. The chloride flux record (Figure $3 \mathrm{e}$ ) shows nearly the same pattern of variability as the stream discharge and chloride concentration records except for the year of 1959 when chloride flux reached at one of the highest values in the record.

[12] In the lower basin, the relationship between the lake volume of the Falcon Reservoir and the PDO index is inconsistent. Some lake-volume minima coincide with minima in the PDO index, and others coincide with maxima in the PDO index (Figures $4 \mathrm{a}$ and $4 \mathrm{~b}$ ). The amount of reservoir release is generally dependent on the reservoir storage, as higher reservoir storage tends to release more water and vice versa (Figures $4 b$ and $4 c$ ). The chloride concentration at Falcon is related to the reservoir storage, but there was a $60 \mathrm{mg} \mathrm{L}^{-1}$ increase in chloride concentration from 1970 to 1990. There are approximately 10 peaks in the chloride concentration record. Six of them (labeled $1,3,4,5,7$, and 8) tend to be associated with minima in the PDO index while the others (labeled 2, 6, 9, and 10) coincide with maxima in the PDO index. Variations in chloride flux are similar to those of stream discharge (Figure 4e), in which larger flow usually leads to larger chloride flux and vice versa.

\section{Discussion}

[13] Chloride is a useful environmental tracer [Feth, 1981] and indicative of water chemistry. The chloride concentration record from the El Paso station indicates that there has been neither significant increasing nor decreasing trend of chloride concentration over the past 70 years (Figure 3d). The chloride concentration of the upper Rio Grande is correlated with the PDO index $(r=$ $-0.19, n=840)$. The chloride record from El Paso shows a distinct pattern of decadal variability, 


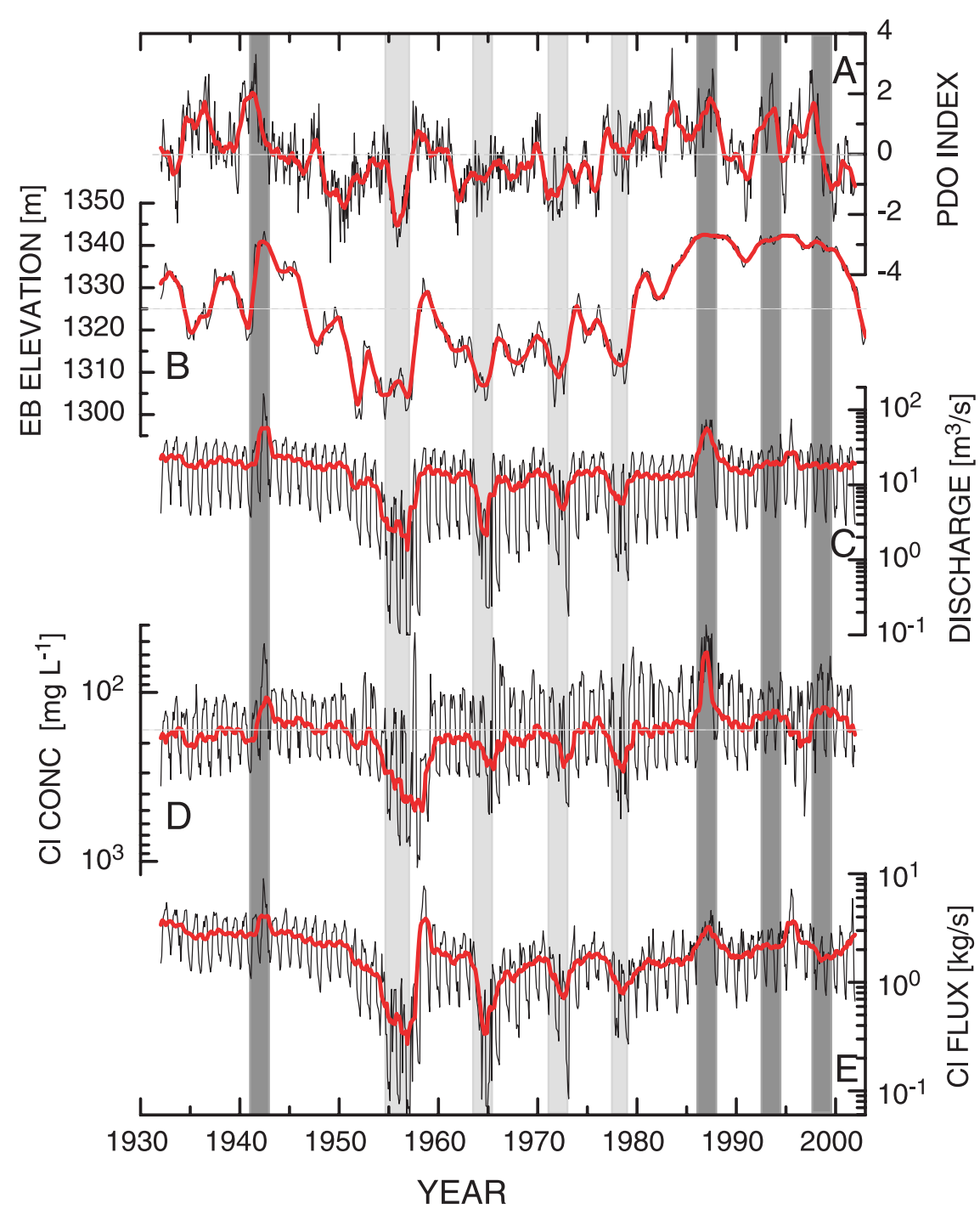

Figure 3. Comparison of the upper Rio Grande hydrologic and chemical variables to the PDO index. (a) The time history of the PDO index [Mantua et al., 1997]. (b) Time series of lake elevation of the Elephant Butte Reservoir (original data from the U.S. Bureau of Reclamation). (c) Time series of stream discharge rate at the El Paso gauging station. (d) Time series of chloride concentration of river water at the El Paso gauging station. (e) Time series of chloride flux at the El Paso gauging station. The chloride flux is estimated through flow-weighted chloride concentration multiplied by mean discharge rate in a given month and divided by 1000 for unit conversion. Note that the scale of the $y$ axis $(\mathrm{Cl}$ concentration) is reversed to facilitate data comparison. Original discharge and chloride concentration data are extracted from the IBWC Water Bulletin. The red thick curves represent smoothed data through 12-point moving averaging to emphasize low-frequency variability. Vertical light and dark gray bars denote significant dry and wet events that are associated with the decadal scale climatic oscillations.

suggesting that climatic oscillations are the dominant sources of long-term changes in river chemistry of the upper Rio Grande.

[14] The relationship between the El Paso chloride concentration and the PDO index observed is not surprising, because (1) stream discharge in the upper Rio Grande is related to the PDO and (2) chloride concentration is largely related to the amount of stream discharge. Streamflow at El Paso is dependent on the reservoir storage of the Elephant Butte which receives runoff mainly from snowmelt of the southern Rocky Mountains. The winter precipitation is known to be associated with the PDO [Gershunov and Barnett, 1998; Gutzler et $a l ., 2002]$. On the other hand, the chloride concentration at El Paso is related to the amount of stream discharge. This relationship can be best described by a $\log$ linear equation: $\log [C l]=2.57-0.38$ $\log [Q]$, in which $\mathrm{Cl}$ is the chloride concentration 


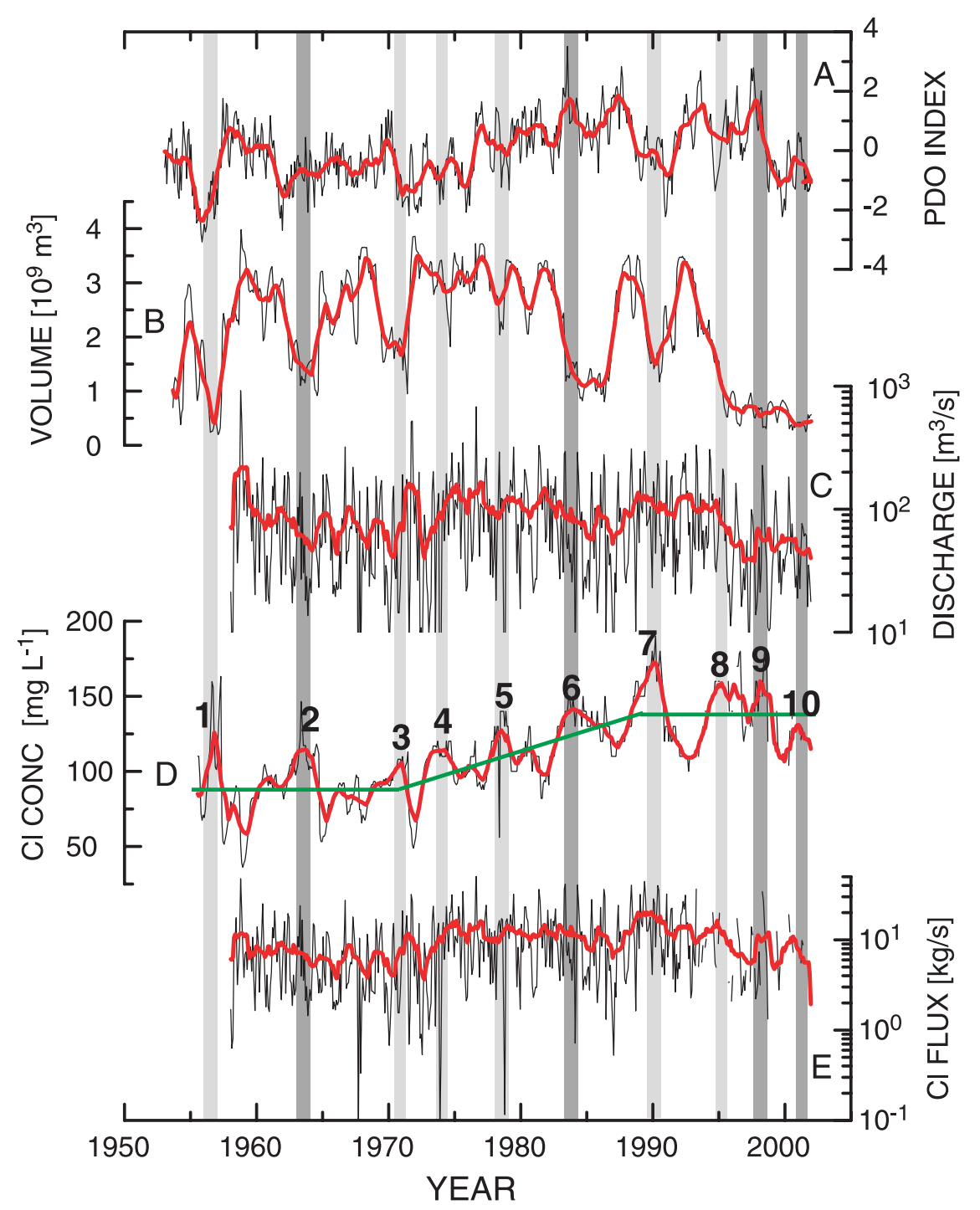

Figure 4. Comparison of the lower Rio Grande hydrologic and chemical variables to the PDO index. (a) Time series of the PDO index [Mantua et al., 1997]. (b) Time series of lake volume of the Falcon Reservoir. (c) Time series of stream discharge at the Falcon Dam gauging station. (d) Chloride concentration record of the water presented at the Falcon Dam gauging station. (e) Time series of chloride flux at the Falcon Dam gauging station. Original lake volume, discharge, and chloride concentration data are taken from IBWC. As in Figure 3, the red thick curves are smoothed data. Vertical light and dark gray bars highlight the chloride maxima that are associated with minima (labeled 1, 3, 4, 5, 7, and 8) and maxima (labeled 2, 6, 9, and 10) in the PDO index. The thick green lines denote the overall trends of chloride concentration.

$\left(\mathrm{mg} \mathrm{L}^{-1}\right)$ and $Q$ is the stream discharge $\left(\mathrm{m}^{3} / \mathrm{s}\right)$. The strong correlation $(r=-0.87, n=840)$ suggests that changes in chloride concentration at El Paso are likely to be controlled by some simple physical processes such as water dilution and evaporative concentration. Besides, the relatively low slope (0.38) of the log linear equation indicates that the presence of additional chloride sinks/sources (e.g., irrigated lands) that likely buffer the effects of water dilution and evaporative concentration. This is consistent with the fact that the chloride flux does not remain constant over time (Figure 3e). Dissolved salts tend to be stored in irrigated lands during low-flow periods and be washed out during the first high-flow years after a drought period [Hernandez, 1978]. For example, the anomalous high chloride flux in 1958 was most likely resulted from leaching salts that were stored in irrigated lands during the drought period beginning in 1954/ 55. In addition, the chloride concentration is strongly correlated with the concentrations of other major ions at El Paso (Table 2), also suggesting that 


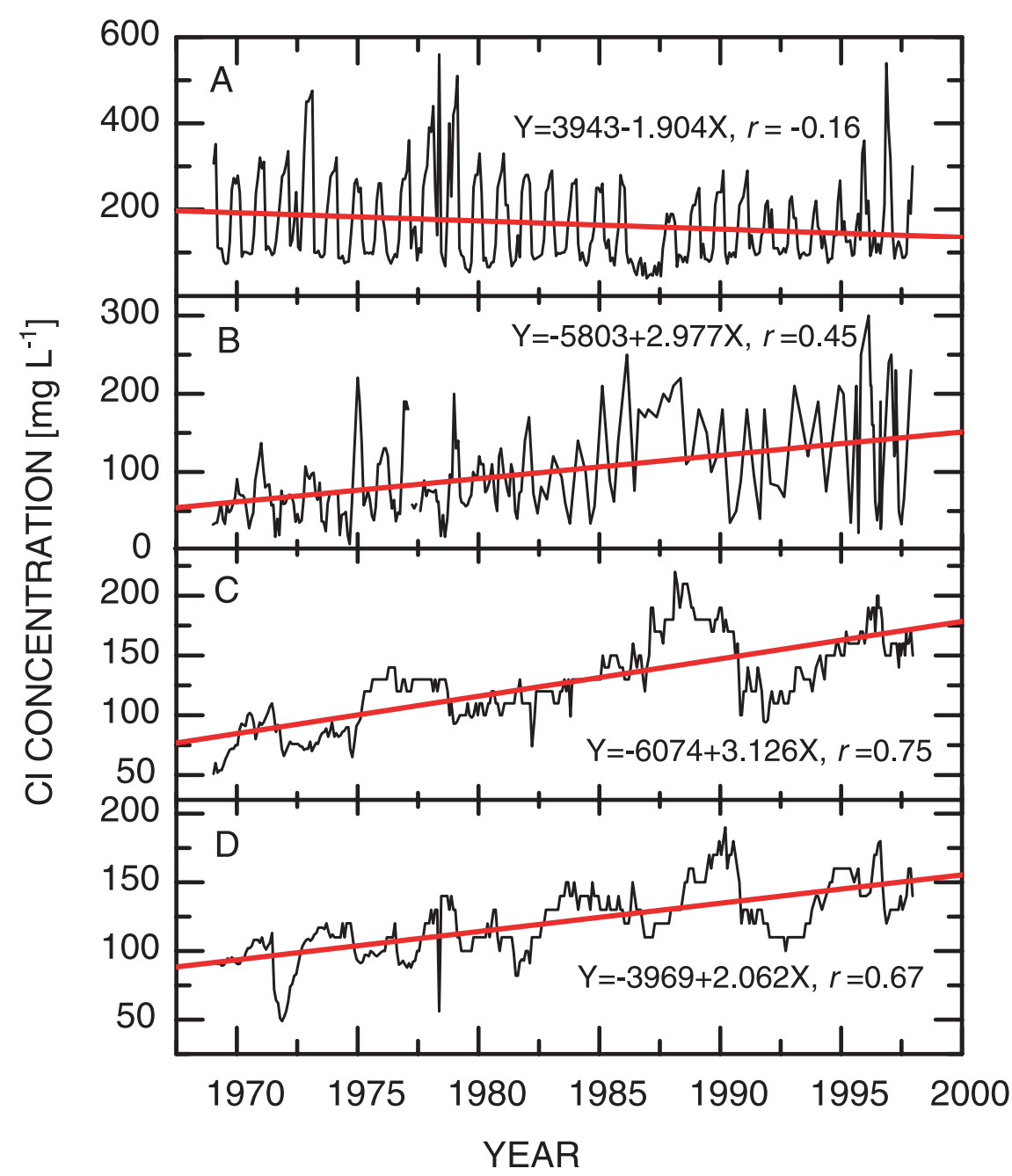

Figure 5. Chloride concentration records from the four selected gauging stations along the Rio Grande: (a) El Paso, (b) Foster Ranch, (c) Amistad Dam, and (d) Falcon Dam. Red straight lines denote the overall trends of chloride concentration at each station.

water dilution and evaporative concentration are the primary processes that affect river chemistry.

[15] In contrast, there is no straightforward relationship between the chloride concentration and the PDO in the lower Rio Grande. This is because (1) the correlation between the PDO and stream discharge is statistically very weak $(r=0.07, n=$ $580)$ and (2) chloride concentration is also weakly correlated with stream discharge $(r=-0.13, n=$ 488). The lower Rio Grande receives river water from several tributaries that have different moisture origins. The summer monsoon rainfall is believed to be a major moisture source for the lower Rio Grande. An analysis of relationship between the Rio Conchos flow and the Southern Oscillation Index (SOI) suggests that the ENSO events exert only a minor influence on the headwaters of the Rio Conchos [Earl and Harrington, 1994]. On the other hand, the weak correlation of chloride concentration and stream discharge is likely induced by considerably different water chemistry of the tributaries. For example, the major element composition is $\mathrm{Ca}-\mathrm{HCO}_{3}$ dominated in the Devils River and $\mathrm{Na}-\mathrm{Cl}$ dominated in the Pecos River. The hydrographs of the tributaries are not always same because the monsoonal rainfall pattern is spatially variable due to its mesoscale controlling dynamics. A disproportional mixing of river waters from the tributaries likely results in a weak relationship between chloride concentration and stream discharge.

[16] It is interesting to note that the chloride concentration at Falcon increased progressively during the PDO transition interval (1970-1990). To address the significance of this chloride trend, four chloride records from the Rio Grande span- 
ning 1969 to 1997 are compared (Figure 5). Again, there is no statistically significant trend of chloride concentration in the upper basin (Figure 5a). However, three chloride records from the lower basin display a similar increasing trend and nearly concurrent oscillations in chloride concentration at the three stations of Foster Ranch, Amistad and Falcon (Figures 5b, 5c, and 5d). This indicates a watershed-scale persistence of increases in chloride concentration along the lower Rio Grande. The causes of the increases in chloride concentration are yet to be determined, but may be induced by constructions of the Amistad and El Granero reservoirs, both of which were completed in 1968, and increased irrigation demands. Besides, some of the small chloride excursions superimposed on the increasing chloride trend may be related to salt accumulation and leaching processes that occur on the irrigated lands and riparian zones.

\section{Summary and Conclusions}

[17] The database studied contains daily to monthly resolved streamflow, lake elevation/volume and chloride concentration records at the two sites spanning the last 50-70 years, allowing us to examine long-term variability in river chemistry along the Rio Grande. The chloride concentration record from the upper basin displays a distinct pattern of decadal variability, in which the chloride concentration at El Paso is lower than average when the PDO is in positive/warmer phase and higher than average when the PDO is in negative/ colder phase. This indicates that the chloride concentration at El Paso is connected with the PDO. This connection is attributed to the facts that (1) the chloride concentration is dependent on stream discharge at El Paso, (2) the stream discharge is determined primarily by winter precipitation in the headwaters region, and (3) the winter precipitation is closely related to the PDO. Moreover, there has been neither significant increasing nor decreasing trend of chloride concentration in the upper basin over the last 70 years. The chloride concentration is strongly correlated with the concentrations of other major ions at El Paso. The analysis of this work suggests that climatic oscillations are the dominant sources of long-term changes in river chemistry of the upper Rio Grande. On the contrary, no such pattern of decadal variability is evident in the lower basin. This may be ascribed to the scatter nature of summer monsoon rainfall and different water chemistry among the tributaries. Instead, the chloride concentration records from the lower basin contain a watershed-scale increasing trend of chloride concentration from 1970 to 1990 . This suggests that in the lower Rio Grande anthropogenic disturbances (e.g., dam constructions and increased irrigation demands) may also be an important factor in affecting river chemistry.

\section{Acknowledgments}

[18] This work was in part supported by the Texas High Education Coordinating Board through an ATP project. The first author wishes to thank the Agricultural Research and Extension Center of the Texas A\&M University for the unique opportunity in studying the Rio Grande. We gratefully acknowledge fellows in IBWC, BOR, and USGS who have made their data accessible to the general public. Lastly, we thank two anonymous reviewers for their valuable criticisms and constructive comments on an earlier version of this manuscript.

\section{References}

Adams, D. K., and A. C. Comrie (1997), The North American monsoon, Bull. Am. Meteorol. Soc., 78(10), 2197-2213.

Chen, J., F. Wang, X. Xia, and L. Zhang (2002), Major element chemistry of the Changjiang (Yangtze River), Chem. Geol., 187, 231-255.

Clark, F. W. (1924), Data of Geochemistry, 770 pp., U.S. Govt. Print. Off., Washington, D. C.

Clark, G. M., R. E. Broshears, R. P. Hooper, and D. A. Goolsby (2003), Evaluating the influence of source basins on downstream water quality in the Mississippi River, J. Am. Water Resour. Assoc., 38(2), 803-818.

Dekov, V. M., A. Van Put, R. Van Grieken, Z. Komy, and F. Araujo (1997), Chemical composition of sediments, suspended matter, river water and ground water of the Nile (Aswan-Sohag traverse), Sci. Total Environ., 201(3), 195210.

Earl, R. A., and J. A. Harrington, Jr. (1994), Relationship of Rio Grande headwaters precipitation and discharge to the southern oscillation index, in Papers and Proceedings of Applied Geography Conferences, pp. 16-24, State Univ. of New York at Binghamton, Binghamton.

Feth, J. H. (1981), Chloride in nature continental water, U.S. Geol. Surv, Water Supply Pap., 2176, 36 pp.

Gershunov, A., and T. P. Barnett (1998), Interdecadal modulation of ENSO teleconnections, Bull. Am. Meteorol. Soc., 79(12), 2715-2726.

Gibbs, R. J. (1970), Mechanisms controlling world water chemistry, Science, 170(3962), 1088-1090.

Gibbs, R. J. (1972), Water chemistry of the Amazon River, Geochim. Cosmochim. Acta, 36(9), 1061-1066.

Gutierrez, M., and P. Borrego (1999), Water quality assessment of the Rio Conchos, Chihuahua, Mexico, Environ. Int., 25(5), 573-583.

Gutzler, D. S., D. M. Kann, and C. Thornbrugh (2002), Modulation of ENSO-based long-lead outlooks of Southwestern U.S. winter precipitation by the Pacific Decadal Oscillation, Weather Forecast., 17(6), 1163-1172.

Hamlet, A. F., and D. P. Lettenmaier (1999), Columbia River streamflow forecasting based on ENSO and PDO climate signals, J. Water Resour. Planning Manage., 125(6), 333341. 
Hernandez, J. W. (1978), Interrelationship of ground and surface water quality in the El Paso-Juarez and Mesilla Valleys, Nat. Resour. J., 18, 1-9.

Hitchon, B., A. A. Levinson, and S. W. Reeder (1969), Regional variations of river water composition resulting from halite solution, Mackenzie River drainage basin, Canada, Water Resour. Res., 5(6), 1395-1403.

Hu, M.-H., R. F. Stallard, and J. M. Edmond (1982), Major ion chemistry of some large Chinese rivers, Nature, 298, 550553.

International Boundary and Water Commission (2001), Flow of the Rio Grande and related data from Elephant Butte Dam, New Mexico to the Gulf of Mexico, Water Bull. 71, Int. Boundary and Water Comm., United States and Mexico, El Paso, Tex.

Kempe, S. (1983), Impact of Aswan High Dam on water chemistry of the Nile, in Transport of Carbon and Minerals in Major World Rivers, Part 2, edited by E. T. Degens, S. Kempe, and H. Soliman, pp. 401-423, SCOPE/UNEP Sonderbd., Mitt. Geol. Palaontol. Inst., Univ. Hamburg, Germany.

Levinson, A. A., B. Hitchon, and S. W. Reeder (1969), Major element composition of the Mackenzie river at Norman Wells, N. W. T., Canada, Geochim. Cosmochim. Acta, 33(1), 133-138.

Livingstone, D. A. (1963), Chemical composition of rivers and lakes, U.S. Geol. Surv. Prof. Pap., 440-G, 63 pp.

Mantua, N. J., and S. R. Hare (2002), The Pacific Decadal Oscillation, J. Oceanogr., 58(1), 35-44.

Mantua, N. J., R. C. Francis, S. R. Hare, Y. Zhang, and J. M. Wallace (1997), A Pacific interdecadal climate oscillation with impacts on salmon production, Bull. Am. Meteorol. Soc., 78(6), 1069-1079.

Markewitz, D., E. A. Davidson, R. O. De Figueiredo, R. L. Victoria, and A. V. Krusche (2001), Control of cation concentrations in stream waters by surface soil processes in an Amazonian watershed, Nature, 410(6830), 802-805.

Miyamoto, S. (1996), Salinity of the Rio Grande: Trend and management implications, Terra, 14(3), 265-278.
National Resource Committee (1938), Regional Planning: Part VI, The Rio Grande Joint Investigation in the Upper Rio Grande Basin, Colorado, New Mexico, and Texas, 1936-1937, U.S. Govt. Print. Off., Washington, D. C.

Neal, E. G., M. Todd Walter, and C. Coffeen (2002), Linking the pacific decadal oscillation to seasonal stream discharge patterns in Southeast Alaska, J. Hydrol., 263(1-4), 188197.

Phillips, F. M., S. Mills, J. M. H. Hendrickx, and J. Hogan (2003), Environmental tracers applied to quantifying causes of salinity in arid-region rivers: Results from the Rio Grande Basin, Southwestern USA, Develop. Water Sci., 50, 327334.

Rasmussen, E. M., and J. M. Wallace (1983), Meteorological aspects of the El Niño/Southern Oscillation, Science, 222, $1195-1202$.

Reeder, S. W., B. Hitchon, and A. A. Levinson (1972), Hydrogeochemistry of the surface waters of the Mackenzie River drainage basin, Canada: I, Factors controlling inorganic composition, Geochim. Cosmochim. Acta, 36(8), 825-865.

Stallard, R. F., and J. M. Edmond (1981), Geochemistry of the Amazon: 1. Precipitation chemistry and the marine contribution to the dissolved load at the time of peak discharge, J. Geophys. Res., 86(C10), 9844-9858.

Stallard, R. F., and J. M. Edmond (1983), Geochemistry of the Amazon: 2. The influence of geology and weathering environment on the dissolved load, J. Geophys. Res., 88(C14), 9671-9688.

Stallard, R. F., and J. M. Edmond (1987), Geochemistry of the Amazon: 3. Weathering chemistry and limits to dissolved inputs, J. Geophys. Res., 92(C8), 8293-8302.

Wilcox, L. V. (1957), Analysis of salt balance and salt-burden data on the Rio Grande, in Problems of the Upper Rio Grande: An Arid Zone River, edited by P. C. Duisberg, pp. 39-44, U.S. Comm. for Arid Resour. Impr. and Dev., Socorro, N. M.

Zhang, Y., J. M. Wallace, and D. S. Battisti (1997), ENSO-like interdecadal variability: 1900-93, J. Clim., 10(5), 10041020. 